ELORE (ISSN 1456-3010), vol. 17 - 2/2010.

Julkaisija: Suomen Kansantietouden Tutkijain Seura ry.

[http://www.elore.fi/arkisto/2_10/makkonen_2_10.pdf]

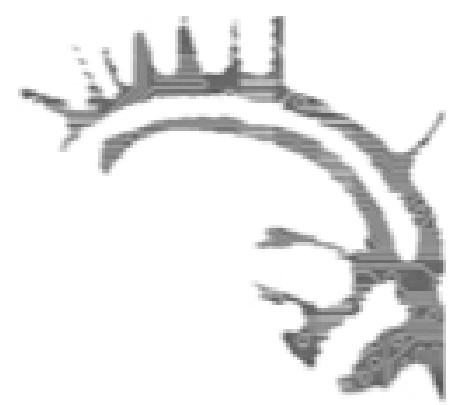

KIRJA-ARVIO

\title{
MUISTETUN, NEUVOTELLUN JA KEKSITYN MENNEISYYDEN ÄÄ- RELLÄ
}

KNUUTTILA, SEPPO \& PIELA, ULLA 2007: Menneisyys on toista maata. Kalevalaseuran vuosikirja 86. Helsinki: SKS. 355 sivua.

Elina Makkonen

Kalevalaseuran 86. vuosikirjassa pohditaan monipuolisesti, kuinka menneisyyttä on tuotettu eri aikoina ja erilaisissa yhteyksissä. Kirjan nimellä Menneisyys on toista maata halutaan tuoda esille menneen täydellisen kuvaamisen haasteellisuutta ja mahdottomuutta. Seppo Knuuttila toteaa artikkelikokoelman johdantosanoissa, että menneisyyden esityksissä pyritään kertomaan, mitä on tapahtunut, mutta myös tarkastelemaan sitä, miten asioiden olisi haluttu olevan tai miten niiden olisi pitänyt olla. Menneisyys näyttäytyykin monisäikeisenä: se voidaan esittää monin tavoin ja se taipuu monenlaisiin tulkintoihin, joista mitkään eivät ole sinällään oikeita tai vääriä.

Kirja on sisällöllisesti kiinnostava, runsas ja erilaisia näkökulmia avaava. Menneisyyttä ja mennyttä lähestytään monien eri tieteenalojen kautta. Kirjassa pohditaan muiden muassa kysymyksiä siitä, mikä merkitys menneisyydellä on yksilön elämässä ja minäkuvan rakentamisessa, millaisena mennyt näyttäytyy elokuvissa, kaunokirjallisuudessa, omaelämäkerroissa ja yleensä muistitiedossa sekä miten menneisyyttä tuotetaan museoissa tai kulttuurimatkailussa.

Kirja koostuu, johdanto mukaan lukien, 21 kirjoituksesta. Ne on jaettu neljään teemalliseen kokonaisuuteen, joiden otsikot ovat "Menneen lähteet", "Menneen kertaus", "Menneen rajat" ja "Mahdolliset menneisyydet". Osa kirjoituksista on perusteellisia ja aiheeseensa syvällisesti perehdyttäviä artikkeleita, kun taas toisia voi pitää ennemminkin esseinä tai katsauksina. 
Elina Makkonen: Muistetun, neuvotellun ja keksityn menneisyyden äärellä

\section{KirJoitetTU, KUUltu JA PUHUTTU MENNEISYYS}

Nostalgia on yksi keskeisistä menneisyyden tutkimuksessa esille tulevista käsitteistä. Kirjan ensimmäisen jakson kirjoittajista Anni Vilkko ja Helmi Järviluoma hyödyntävät nostalgiatutkija Svetlana Boymin käsiteparia restoratiivinen ja reflektiinen nostalgia. Restoratiivinen on entistävää ja palauttavaa nostalgiaa, jolle on tyypillistä ajan tilallistaminen. Se suuntautuu traditioihin ja pysyvyyteen. Sen sijaan reflektiiviselle eli pohtivalle nostalgialle on tyypillistä tilan ajallistaminen. Se on uutta luovaa ja tiedostaa etäisyyden menneeseen, mutta myös menneen ja nykyisen yhtymäkohdat ja vastaavuudet.

Vilkko lähestyy nostalgiaa paikkojen ja tilojen tutkimuksen ja erityisesti kodin kaipuuseen ja kotoiseen liittyvien pohdintojen kautta. Järviluoma puolestaan tarkastelee menneisyyttä muisteltujen kuulokuvien näkökulmasta. Hän analysoi projektin Sata suomalaista äänimaisemaa (2004-06) aikana järjestetyn keruukilpailun tuloksena syntyneitä kirjoituksia. Järviluoma tutkii sitä, millainen kertojan asenne, tunnetila ja tulokulma on ollut hänen vertaillessaan mennyttä ja nykyistä äänimaisemaa. Keruuvastauksisssa tulee esille niin neutraaleja kuin hieman tai erittäin negatiivisia, mutta myös pohtivia tai positiivisia nykyisen äänimaiseman kuvauksia.

Mari Hatakan artikkelin taustalla ovat kahdessa eri keruussa (Satasärmäinen nainen ja Eläköön mies) kootut omaelämäkerralliset tekstit, joista hän on muodostanut aineiston omaa väitöstutkimustaan varten. Vuosikirjan artikkelissa kirjoittaja keskittyy analysoimaan 1920-luvulla syntyneen, väkivaltaisessa avioliitossa eläneen Lahjan kirjoitusta. Hatakka toteaa, että elämäkerroissa kirjoittaja pyrkii luomaan elämästään kokonaiskuvan ja solmimaan ikään kuin sovinnon elämänsä ja itsensä kanssa. Yhdeksi keskeiseksi strategiaksi Lahjan kohdalla nousee kristillinen diskurssi. Se antaa valmiin kuuliaisen ja nöyrän vaimon roolin sekä auttaa kirjoittajaa tekemään sovintoa oman elämänsä kanssa kristinuskon avulla.

Maarit Knuuttila tarkastelee Lapsuuden ruokamuistoja -aineiston pohjalta kysymyksiä siitä, miten menneisyyden ruokatavat muistetaan ja kuinka niitä nykyisyydestä käsin arvotetaan sekä miksi omavaraista elämäntapaa ja sen tuottamia ruuanhankinnan keinoja edelleenkin pidetään hyväksi koetun ruuan perustana. Vaikka omavarainen elämäntapa on konkreettisesti kadonnut, on se suomalaisille tuttu kollektiivisena kertomuksena ja vaikuttaa myös keittämisen ideaaleihin. Knuuttila toteaa, että nostalgisoituun menneisyyden keittöön liitetään vain nykyisyydestä katsoen parhaana pidetyt ulottuvuudet. Keittämistarinat eivät tuota yksinomaan tulkintaa hyvästä menneisyydestä, vaan esille tulee myös elämän raskaus ja ruuallinen niukkuus.

Pirkko Nuolijärven artikkelissa keskitytään kirjallisen muistitiedon sijaan puheeseen. Nuolijärvi pohtii artikkelissaan menneisyyden esillekutsumista murrehaastattelussa. Murrehaastatteluissa, jotka tehtiin pääasiassa 1960-luvulla, pyrittiin kokoamaan mahdollisimman vanhakantaista paikallismurretta ja ajateltiin sen onnistuvan parhaiten silloin, kun haastateltavilta kysytään entisaikain elämästä. Kirjoittaja keskittyy tarkastelussaan erityisesti haastattelijan esittämien kysymysten merkitykseen 
Elina Makkonen: Muistetun, neuvotellun ja keksityn menneisyyden äärellä

ja toteaa, että ne vaikuttavat siihen, mihin asioihin muistelija keskittyy ja miltä menneisyys haastatteluissa näyttää.

\section{MENNEEN KERTAUSTA JA VALIKOINTIA}

Kirjan toisen jakson aloittavassa Kirsi Saarikankaan artikkelissa käsitellään lähiötiloja. Saarikangas hyödyntää lähiöasukkaiden kirjallista muistitietoa, jota on kerätty 1990luvun puolivälistä 2000-luvun alkuun. Vaikka lähiöt onkin julkisessa kirjoittelussa, kaunokirjallisuudessa ja tutkimuksissa usein esitetty huonossa valossa, tulee lähiöasukkaiden omissa kirjoituksissa esille jopa nostalgisia sävyjä ja hyvin aistivoimaisia muistikuvia. Asukkaiden kirjoituksia voidaankin pitää vastakertomuksina. Erityisen ansiokasta Saarikankaan artikkelissa on se, että hän entisenä lähiöasukkaana ottaa huomioon osallisuutensa eli omien kokemustensa ja muistojensa vaikutuksen tutkimukseensa.

Hanna Kuusen ja Anu Koivusen artikkeleissa liikutaan elokuvan parissa. Kuusi pohtii artikkelissaan nostalgiaa kahden 1990-luvulla tehdyn, 1950-luvulle ajoittuvan elokuvan kautta (Markku Pölösen Kuningasjätkä ja Pekka Mandartin Keisarikunta). $\mathrm{Ne}$ ovat tekijöidensä mukaan tarkoitettu nostalgisiksi ja ne myös koettiin nostalgisina lähimenneisyyden kuvauksina. Kuusen mukaan Suomessa on tyypillistä se, että elokuvien ja muidenkin kulttuurituotteiden vastaanotossa huomiota kiinnitetään todenmukaisuuteen. Pölösen katsottiin romantisoineen tukkilaisuutta, kun taas Mandartin kuvausta sataman kapakka- ja muusikkoelämästä pidettiin liian siveänä.

Anu Koivusen myötä kirjassa siirrytään 1970-luvulle ja dokumenttielokuvan pariin. Jouko Aaltosen Kenen joukoissa seisot on havainnoiva, laululiikkeestä kertova ja Lasse Naukkarisen Olipa kerran utopia taas henkilökohtainen dokumenttielokuva. Vaikka elokuvat ovat muodoltaan erilaisia, molemmissa utopia ja utooppisuus nousee 1970-luvun muistelemisen keskeiseksi teemaksi ja muodoksi. Koivusen mukaan nostalgian tai kaipuun kohteeksi näissä elokuvissa nousee toive ja tunne paremmasta tulevaisuudesta.

Toisen jakson kahta viimeistä, Sven-Erik Klinkmanin ja Janne Vilkunan, artikkelia yhdistää ajatus muistin valikoivasta luonteesta. Klinkman käsittelee perusteellisessa artikkelissaan kolmen vaasalaismuusikon erilaista tapaa konstruoida hyvää menneisyyttä musiikissaan ja kertomuksissaan. Klinkmanin tarkastelun lähtökohtana on ajatus siitä, että hyvää menneisyyttä konstruoidessaan yksilö valitsee tiettyjä muistamisen ja pohdiskelemisen arvoisia seikkoja, jolloin taas toiset, vähemmän muistamisen arvoiset seikat unohtuvat tai unohdetaan. Vilkuna jatkaa samansuuntaista pohdintaa todetessaan, että myös museoissa unohdetaan. Valinnat siitä, mitä kerätään ja hyväksytään osaksi museoiden kokoelmia, mutta myös se, miten valitut objektit luokitellaan, kertovat kulloisenkin ajan ja kulttuurin arvoista. 
Elina Makkonen: Muistetun, neuvotellun ja keksityn menneisyyden äärellä

\section{MENNEEN RAJAT}

Kirjan kolmannen jakson aloittaa Tiina Mahlamäen artikkeli siitä, miten ja millaisena kirjailija Eeva Joenpelto muistaa ja muistelee 1930-luvun Lohjaa sekä miten paikkakuntaa kuvataan Joenpellon kirjoittamassa Lohja-sarjassa. Kirjoittaja huomauttaa, ettei tarkastele ja tulkitse kirjailijan elämää tämän teosten kautta ja avulla, jos kohta teoksista voikin lukea kirjailijan elämänvaiheita. Mahlamäki toteaa joutuneensa Joenpellon elämäkertaa kirjoittaessaan pohtimaan muistamista, unohtamista ja "väärin muistamista". Vaikka tutkija on kuunnellut mahdollisimman tarkasti haastatteluissa ja kirjoituksissa kuuluvaa Joenpellon "omaa ääntä", on hän samalla suhtautunut siihen epäluuloisesti ja etsinyt myös aukkoja, puutteita ja väärinymmärryksiä.

Risto Turusen artikkelissa menneisyyttä tarkastellaan kirjallisuudentutkimuksen näkökulmasta. Hyvän menneisyyden kaipuu näyttää olleen ja olevan edelleen keskeinen motiivi suomalaisen romaanikirjallisuuden tematiikassa. Turunen kuljettaa lukijaa kansanrunouden, joidenkin Runebergin ja Aleksis Kiven teosten, historiallisten romaanien, Karjala-kuvausten ja Väinö Linnan Täällä Pohjantähden alla -trilogian kautta nykyromaaneihin, joita käsittelee tarkemmin. Monille nykyromaanien päähenkilöille menneisyys on paikka, jonne he haluavat paeta ahdistusta, näköalattomuutta ja erilaisia vaatimuksia. Etenkin miesten kirjoittamalle nykykirjallisuudelle on ominaista ironia ja viisto katse menneeseen (s. 213).

Jan Čermákin artikkelissa tarkastelun kohteena on kaksi eurooppalaista eeposta, Kalevala ja Beowulf. Kirjoittajan mukaan Kalevalan rakenteellinen metafora on horisontaalinen, kun taas Beowulfin muotoa voidaan verrata vertikaaliin. Beowulfin aikataso on pakanallis-kristillinen ja siten kaksitasoinen, kun taas kalevalainen aikakäsitys on yhtenäisempi. Čermák toteaa Kalevalan olevan Suomen kirjallisuuden peruskivi, joka luo kansallista menneisyyttä. Sen sijaan kristillisen ja esikristillisen ajan kohtaamista kuvaavalla Beowulfilla ei ole sanottavaa vaikutusta myöhempään englantilaiseen kirjallisuuteen.

Anne Heimo käsittelee artikkelissaan Elias Lönnrotia ja hänen kotipaikkakuntaansa Sammattia. Heimo keskittyy erityisesti siihen, mitä sammattilaiset Lönnrotista ajattelivat ja miten hän on vaikuttanut vuoden 1918 tulkintoihin paikkakunnalla. Lönnrotin omalaatuinen persoonallisuus ja monipuolinen elämäntyö antavat mahdollisuuden monenlaisille tulkinnoille. Sammattilaisille Lönnrot oli paitsi valtakunnallinen suurmies, joka loi Kalevalan ja oli monipuolinen kulttuurivaikuttaja, myös oikeamielinen ja tasavertaisuuteen pyrkivä ihminen samoin kuin hyvä isäntä ja köyhien ystävä. On kiinnostavaa, että Lönnrotia käytettiin sisällissotaan liittyvissä tulkinnoissa sekä valkoisten että punaisten esikuvana. Heimon mukaan Lönnrotia koskevista kertomuksista piirtyy eräänlainen paikallinen utopia Sammatista.

Hanna Snellmanin artikkelin myötä kirjassa siirrytään Ruotsiin ja sinne muuttaneiden suomalaisten kertomuksiin. Snellmanin kirjoitus pohjautuu Surahammarin Virsbon suomalaisyhteisössä 1970-luvulla tehtyihin haastatteluihin ja valokuva-aineistoon. Vaikka lähtömaa Suomi esiintyykin muuttokertomuksissa kaivattuna satumaana, niin todellisuudessa se ei ole pystynyt tarjoamaan lähtijälle koulutus- 
mahdollisuuksia tai työpaikkaa. Virsbolaiset haastateltavat näyttävät viihtyvän hyvin Ruotsissa eivätkä 1970-luvulla ole juurikaan elätelleet paluumuuttohaaveita. Suomeen ollaan kyllä tiiviissä yhteydessä ja haastateltavat mieltävät itsensä suomalaisiksi, mutta Ruotsi on hyvä kotimaa ja muutto sinne monella tavalla positiivinen asia.

\section{Mahdollinen JA KeKsitTy MENNEISYYS}

Kirjan viimeisen jakson aloittaa Petri J. Raivon artikkeli sotahistoriallisen menneisyyden näkyväksi tekemisen ja tulkitsemisen prosesseista. Raivo kuvaa kiinnostavasti sitä, miten jokin tietty paikka koodataan muistin paikaksi vaikkapa muistomerkin, opaskylttien tai identtisten kopioiden avulla. Aina ei kyse ole autenttisesta tapahtumapaikasta, vaan esimerkiksi siirretystä perinnekorsusta tai uudelleen rakennetusta kohteesta, mutta silti tämä kohde saa näkijässään aikaan autenttisuuden kokemuksen. Raivo muistuttaa, että historialliset tapahtumapaikat muuttuvat muistin paikoiksi merkitsemisen kautta. Merkitseminen ja muistaminen on valikoivaa, mikä taas johtaa pohtimaan sitä, mitä halutaan muistaa ja unohtaa sekä kenen menneisyys saa näkyä ja kenen vastaavasti ei.

Ulla-Maija Peltosen artikkelissa keskitytään muistamisen ja kertomisen politiikkaan Mannerheimiin liittyvien esitysten ja tulkintojen kautta. Peltosen mukaan mielikuvat ja käsitykset Mannerheimista ovat monikerroksisia ja ristiriitaisia, ja ne ovat vaihdelleet eri aikoina. Julkinen Mannerheim-kuva on varsin elitistinen ja jopa kaunisteleva. Kaunokirjallisuus, kuvataide ja folklore vastaavasti ovat kyseenalaistaneet julkista tulkintaa Mannerheimista. Ristiriitainen suhde näkyy esimerkiksi ratsastajapatsaaseen suhtautumisessa. Vaietut käsitykset Mannerheimista välittyvät eritoten vuoden 1918 sisällissotaan liittyvissä kertomuksissa ja pilakuvissa. Niissä Mannerheim kuvataan usein negatiiviseen sävyyn ja esimerkiksi kaskuissa korostetaan hänen huonoa suomenkielen taitoaan.

Pekka Hakamies tarkastelee Karjalankannaksella ja Laatokan Karjalassa 2000-luvun alkupuolella tehtyjen haastattelujen kautta siirtovenäläisten historiakäsityksiä. Kirjoittaja pohtii sitä, millainen kuva sodan aikana tai sen jälkeen Suomen luovuttamaan Karjalaan muuttaneilla neuvostoasukkailla on alueen historiasta. Hakamies toteaa, etteivät uudet asukkaat ole muuttaessaan juurikaan tienneet asuttamansa alueen menneisyydestä. Alkuaikoina alueen suomalaisuutta ei peitelty, mutta myöhempinä vuosikymmeninä siitä vaiettiin. Joidenkin haastateltavien mukaan Kannaksellakin oli sodittu saksalaisia vastaan ja tästä syystä ajateltiin, että luovutetut alueet olisi "vapautettu" fasistien hallusta. Osa haastateltavista taas oli sitä mieltä, että alueen entiset asukkaat olisi karkotettu tai että alue oli alunperinkin kuulunut Venäjälle.

Jukka Korpelan suuria linjoja piirtävässä kirjoituksessa huonontumisen historiasta on paljonkin kiinnostavia näkökulmia ja oivalluksia, mutta mielenkiintoisemmaksi nousee ajatus suomalaisten "me"-näkökulmasta (s. 328). Niin talvisotahistoriassa kuin myös yksityisemmissä muisteluksissa näyttää olevan taustalla käsitys "meidän" maineikkaasta ja kaivatusta menneisyydestä. Ajatus historiasta huononevana tulee 
ilmi muun muassa silloin, kun todetaan nykyisen sukupolven olevan huonompi kuin edellinen tai kun kerrotaan ennen kaiken olleen paremmin. Tällöin ei kuitenkaan haluta kiinnittää huomiota esimerkiksi maalaisyhteisössä elämisen huonoihin puoliin. Korpela muistuttaa, että kun pohditaan, onko maailma huonontunut tai mitä huonontumisen historia oikein tarkoittaa, onkin kyse siitä, mistä näkökulmasta asiaa katsoo.

Kustaa H.J. Vilkuna tarkastelee kirjan päättävässä kirjoituksessa mielekästä menneisyyttä 1800-luvulle ajoittuvien hautauspuheiden ja muistokirjoitusten kautta. Vilkunan mukaan ne olivat julkisen ja virallisen kirjallisen suuren tradition ja pienyhteisön sisäisen ja epävirallisen pienen tradition väliin sijoittuvia menneisyyden kertomuksia. Nämä kertomukset olivat konkreettisia todisteita yhteisön aikaisemmista vaiheista, joilla perusteltiin kerrontahetken olosuhteita. Hautajaisissa pidetyissä puheissa ja ruumissaarnoissa korostettiin vainajan elämäntaipaleen kärsimyksiä, koska niiden kautta voitiin tuottaa tulkintaa oikeasta, hyvästä, jumalaisesta ja samalla esimerkillisestä elämänkulusta. Puheissa punnittiin vainajan elämää menneisyytenä ja kerrottiin elämänvaiheista niitä asioita, joilla oli merkitystä yhteisöllisesti.

Menneisyys on toista maata on erilaisia näkemyksiä ja tulkintoja sisältävä kirja, jossa vuorottelevat erilaisiin muisteluaineistoihin keskittyvät analyysit ja laajemmat menneisyyden tutkimista käsittelevät kirjoitukset. Kautta linjan korostuu se seikka, että mennyttä ja menneisyyttä tulkitaan nykyhetken näkemysten ja arvostusten näkökulmasta. Menneisyys näyttäytyy kirjassa paitsi muistettuna ja unohdettuna niin myös valikoituna, neuvoteltuna ja keksittynä. Vuosikirja osoittaa kiinnostavasti, miten eri tieteenaloja edustavien yksittäisten tutkijoiden tarkasteluissa menneisyyden tutkimisen kysymykset avautuvat ja miten monipuolisesti menneisyyttä ja mennyttä voidaan tarkastella.

\section{Filosofian tohtori Elina Makkonen on kontiolahtelainen perinteentutkija.}

